$\xi=$

\title{
Growth and serum mineral profile of broiler starter fed dried cocoyam tuber (colocasia esculenta) meal
}

\author{
Onyekwere M. U.*, Jiwuba P. C., Okechukwu S. O., Anuonye A. C. \\ Department of Animal Production Technology, Federal College of Agriculture, P.M.B.7008, Ishiagu, Ebonyi State, Nigeria \\ *Corresponding author E-mail: jiwubapc@yahoo.com
}

\begin{abstract}
A 30-day experiment was conducted with 240 unsexed broiler starters to determine the effect of cocoyam tuber meal on growth and serum mineral profile. Four diets were formulated at $0 \%, 10 \%, 20 \%$ and $30 \%$ of cocoyam tuber meal. The birds were assigned the four treatment diets in a completely randomized design and replicated 3 times with 20 birds per replicate. Feed and water were supplied $a d-$ libitum. Data were collected on average daily feed intake, average daily weight gain, feed conversion ratio and blood was sampled from each treatment group, data obtained were analysed statistically. The performance of the broiler starter birds showed significant $(p<0.05)$ difference among the treatment groups. Average daily weight gain was improved $(p<0.05)$ by cocoyam inclusion at $30 \%$ inclusion level. FCR of the birds in treatment groups were significantly $(\mathrm{p}<0.05)$ better than the control. The parameters of serum mineral profile maintained a significant $(\mathrm{P}<0.05)$ difference among the treatments and showed a good evidence of body structural components of the birds. These results showed that inclusion of cocoyam tuber meal had a beneficial effect on performance and structural components of broiler starters. Cocoyam tuber meal inclusion level at $30 \%$ was recommended for optimum broiler starter birds.
\end{abstract}

Keywords: Broilers; Performance; Serum; Mineral Profile and Cocoyam Tuber Meal.

\section{Introduction}

Mineral requirements of broiler birds mainly referred to as inorganic components of feed are classified under macro and micro minerals. These minerals could hardly be met from macro feed ingredients but rather by supplementation and fortification of diets. Macro-minerals like calcium, phosphorus, magnesium, potassium, sulphur, sodium and chlorine are needed in large quantity; while micro minerals for example, iron, zinc, manganese, cobalt and molybdenum are needed in small quantity. The micro mineral sources include periwinkle shell, bone meal and even sodium chloride (Edache et al. 2005)

The requirement of sodium amongst macro minerals is usually met by inclusion of common salt in the diet. However, high dietary level of salt stimulate higher water consumption proportional to the excess salt which in turn causes water droppings and add stress to sick birds (Anon 2002). Generally, chickens can tolerate up to $0.25 \%$ salt in drinking water while higher levels are tolerated in feed, but birds become more susceptible to sodium $\left(\mathrm{Na}^{+}\right)$toxicosis on water intake restriction (MVM 2008).

Minerals function as body structural components and acid-base balance. The requirement of these minerals appears to be higher for warm climates than cold climates (Olumu 2004). Chicken contains four percent mineral water and this is not sufficient for its skeletal body composition. Most minerals used for poultry rearing are supplied artificially and where scarcity of these minerals occur production level of the birds tilt to negative position. As a result of that, it has become imperative to source for alternative natural minerals from crops preferably cocoyam.

Cocoyam tuber is one of the richest sources of carbohydrate which provides energy, folic acid, riboflavin, Vitamin A and C, Calcium and Phosphorus (Agwunobi et al. 2002). The anti-nutritional fac- tors in cocoyam like phytate, oxalates and trypsin inhibitors could be treated by boiling. The study was therefore carried out to determine the growth and serum mineral profile of broiler starters fed cocoyam (Colocasia esculenta) tuber meal.

\section{Materials and methods}

\subsection{Experimental location}

The study was conducted at the poultry unit department of Animal Production, Federal College of Agriculture, Ishiagu, Ebonyi State, Nigeria.

\subsection{Sourcing and processing cocoyam tubers}

Matured cocoyam tubers used for this study were obtained from Akaeze, Ivo Local Government Area of Ebonyi State. The tubers were washed to remove sand and other dirt particles attached to them. This was followed by parboiling for twenty (20) minutes at the temperature of $100^{\circ} \mathrm{C}$ in order to detoxify the anti-nutritional factors in the test ingredient. The tubers were sliced into pieces and sun-dried to crispy state and milled into cocoyam tuber meal before using it to formulate broiler starter feed at dietary level of $0 \%, 10 \%, 20 \%$ and $30 \%$ respectively as presented in table 1 .

\subsection{Management of experimental birds}

The trial which lasted for thirty (30) days was carried out with two hundred and forty (240) day old Marshal Broiler chicks from "COSIN" farm Enugu State. The chicks were subjected to brooding in deep litter system. There were vaccinated against Newcastle disease at day-old and $14^{\text {th }}$ day consequently Gumboro disease 
treatment was done at $9^{\text {th }}$ and $18^{\text {th }}$ day of their life. They were then randomly allocated to four (4) treatments, each having sixty (60) birds and replicated three (3) times with 20 birds per replicate in a completely randomized design. Feed and water were provided adlibitum.

Table 1: Composition of Experimented Diets (\%)

\begin{tabular}{|c|c|c|c|c|}
\hline & \multicolumn{4}{|c|}{ Dietary Levels } \\
\hline Ingredient & 0 & 10 & 20 & 30 \\
\hline Maize & 54.00 & 48.60 & 43.20 & 37.80 \\
\hline СТM & 0 & 5.40 & 10.80 & 16.20 \\
\hline Wheat offal & 6.00 & 6.00 & 6.00 & 6.00 \\
\hline Soybean & 15.00 & 15.00 & 15.00 & 15.00 \\
\hline GNC & 14.00 & 14.00 & 14.00 & 14.00 \\
\hline Fish meal & 4.00 & 4.00 & 4.00 & 4.00 \\
\hline Bone meal & 3.00 & 3.00 & 3.00 & 3.00 \\
\hline Limestone & 2.00 & 2.00 & 2.00 & 2.00 \\
\hline Salt & 0.25 & 0.25 & 0.25 & 0.25 \\
\hline Lysine & 1.25 & 1.25 & 1.25 & 1.25 \\
\hline Methionine & 0.25 & 0.25 & 0.25 & 0.25 \\
\hline Premix & 0.25 & 0.25 & 0.25 & 0.25 \\
\hline Total & 100.00 & 100.00 & 100.00 & 100.00 \\
\hline \multicolumn{5}{|l|}{ Calculated nutrient levels } \\
\hline Crude protein & 21.65 & 21.25 & 20.84 & 20.44 \\
\hline Crude fibre & 3.33 & 3.42 & 3.51 & 3.56 \\
\hline Ether extract & 3.92 & 3.73 & 3.54 & 3.35 \\
\hline $\begin{array}{l}\text { Metabolizeable energy } \\
(\mathrm{kcal} / \mathrm{kg})\end{array}$ & 2855.56 & 2842.92 & 2830.29 & 2817.00 \\
\hline
\end{tabular}

CTM - Cocoyam taro meal.

$\mathrm{G} / \mathrm{NC}$ - groundnut cake.

\subsection{Mineral studies}

At the end of the feeding trial, $4 \mathrm{ml}$ of blood were drawn per replicate using hypodermic sterile needle with syringe. The blood samples were emptied and labeled into a simple bottle without anticoagulant for analysis of minerals. Potassium, Sodium, Magnesium, Iron, Phosphorus, and Calcium were determined according to the method of flame photometry (Henry et al. 1972) while proximate analyses of the diets and cocoyam tuber meal were determined using the method of (AOAC 1999)

\subsection{Statistical analysis}

All data collected were subjected to analysis of variance (ANOVA). Difference between treatments means were separated using Duncan's New Multiple Range Test (Duncan 1955).

\section{Results and discussion}

\subsection{Proximate compositions}

The result of proximate analysis presented on Table 2 indicated that crude fibre (CF) and ash increased in their values as dietary levels increased. This was similar to the result obtained by (Okon et al. 2007) who made similar observation using cocoyam as test ingredient on quail birds. All other parameters had corresponding values and this could be attributed to maximum elimination of toxic effect from test ingredient by boiling.

Table 2: Proximate Analysis of Cocoyam and Experimental Diets

\begin{tabular}{lllll}
\hline \multicolumn{5}{l}{ Composition $(\%)$} \\
\hline Nutrient & Cocoyam & 10 & 20 & 30 \\
Crude protein $(\mathrm{CP})$ & 8.40 & 23.04 & 23.85 & 22.69 \\
Crude fibre $(\mathrm{CF})$ & 1.49 & 3.67 & 3.70 & 3.75 \\
Ether extract & 4.22 & 3.57 & 3.54 & 3.45 \\
Ash & 5.12 & 5.00 & 5.02 & 5.73 \\
Gross energy $(\mathrm{kcal} / \mathrm{kg})$ & 1435.21 & 2862.46 & 2863.50 & 2860.50 \\
\hline
\end{tabular}

Values are recorded on three experimented diets.

\subsection{Growth performance}

The performance of the broiler fed cocoyam tuber meal is presented on Table 3. All the parameters examined showed significant difference $(\mathrm{P}<0.05)$ with daily weight gain and feed intake maintaining a progressive increase in values among the treatments. This was in agreement with the finding of Agwunobi et al. (2002) who used weaned rabbits and Okon et al. (2007) who replaced maize with cocoyam on their trials. Daily feed intake were higher and better for the birds fed the diets containing cocoyam tuber meal than the ones fed the control diet; thus an indication of higher palatability of the treatment diets. Strict adherence to proper management practices coupled with saved nature of the test ingredient was attributed to zero mortality recorded among treatments. This was in line with the reports of (Onyekwere et al. 2011) that used toasted velvet beans on nutrient evaluation of broilers.

Table 3: Performance of Broiler Starter Fed Dried Cocoyam Tuber Meal

\begin{tabular}{|c|c|c|c|c|c|}
\hline \multicolumn{6}{|c|}{ Dietary Levels } \\
\hline Parameter & 0 & 10 & 20 & 30 & SEM \\
\hline $\begin{array}{l}\text { Initial body } \\
\text { weight }(\mathrm{g})\end{array}$ & $436.70^{d}$ & $460.00^{\mathrm{a}}$ & $446.70^{\mathrm{b}}$ & $443.30^{\mathrm{c}}$ & 13.50 \\
\hline $\begin{array}{l}\text { Final body } \\
\text { weight }(g)\end{array}$ & $1613.30^{\mathrm{a}}$ & $1766.70^{\mathrm{c}}$ & $1788.30^{\mathrm{b}}$ & $1783.30^{\mathrm{b}}$ & 29.95 \\
\hline $\begin{array}{l}\text { Av. Weight gain } \\
\text { (g) }\end{array}$ & $1776.60^{\mathrm{d}}$ & $1306.70^{\mathrm{c}}$ & $1341.60^{\mathrm{a}}$ & $1340.00^{\mathrm{b}}$ & 22.91 \\
\hline $\begin{array}{l}\text { Daily weight } \\
\text { gain }(\mathrm{g})\end{array}$ & $42.03^{\mathrm{d}}$ & $46.70^{c}$ & $47.58^{\mathrm{b}}$ & $48.03^{\mathrm{a}}$ & 38.55 \\
\hline Feed intake $(\mathrm{g})$ & $2214.80^{\mathrm{d}}$ & $2336.80^{\mathrm{c}}$ & $2362.67^{b}$ & $2400.00^{\mathrm{a}}$ & 30.81 \\
\hline $\begin{array}{l}\text { Daily Feed in- } \\
\text { take }(\mathrm{g})\end{array}$ & $79.10^{\mathrm{b}}$ & $84.46^{\mathrm{a}}$ & $84.38^{\mathrm{a}}$ & $84.38^{\mathrm{a}}$ & 5.81 \\
\hline FCR & $1.88^{\mathrm{a}}$ & $1.79^{\mathrm{b}}$ & $1.77^{\mathrm{c}}$ & $1.76^{\mathrm{c}}$ & 0.86 \\
\hline Feed cost $/ \mathrm{kg} \mathrm{N}$ & $84.98^{\mathrm{d}}$ & $91.28^{\mathrm{c}}$ & $97.03^{\mathrm{b}}$ & $103.28^{\mathrm{a}}$ & 6.17 \\
\hline
\end{tabular}

Different superscript within the same row indicate significant $(\mathrm{P}<0.005)$ difference

\subsection{Serum minerals}

Serum mineral profiles of the birds are presented in Table 4 . There were significant differences $(\mathrm{P}<0.05)$ among all the parameters examined. It was observed that Potassium in zero $(0 \%)$ percent diet level had the lowest values. This may be due to lack of test ingredient inclusion. In addition, Potassium values were relatively below the recommended value of $4.6-6.5 \%$ as reported by (Allele and Mays 1999). The values of Sodium and Calcium fail within the values in literature indicating the usefulness of these minerals for bone formation and blood clotting as reported by (Oko and Agiang 2009). However, the values of Sodium were below 156 $\mathrm{mg}$ as reported by (Isidahomen et al. 2009) in their trial while Calcium values were within the range of $9.0-11.6 \mathrm{mg}$ as reported out by (MVM 2011). Iron and Phosphorous maintained a progressive increase in their values with increasing levels of the test ingredient. This may be attributed to the general acceptability of the diet even though the highest value was recorded at $30 \%$ diet level. In addition, Magnesium values across the treatment groups fall within the normal literature range of 1-6 units as reported by (Allele and Mays 1999). It is important to point out that the impressive performance of the birds using cocoyam diets on treatment 3 when compared with control diet evidently demonstrated the efficiency employed in handling and processing of the test ingredient.

Table 4: Serum Mineral Profile of Broiler Starter Fed Cocoyam Tuber Meal

\begin{tabular}{|c|c|c|c|c|c|}
\hline & Dietary I & evels & & & \\
\hline Serum mineral indices & 0 & 10 & 20 & 30 & SEM \\
\hline Potassium (mlg/l) & $3.05^{\mathrm{d}}$ & $3.07^{\mathrm{c}}$ & $3.10^{\mathrm{a}}$ & $3.08^{\mathrm{b}}$ & 1.12 \\
\hline Sodium (mlg/l) & $144.50^{\mathrm{d}}$ & $148.10^{\mathrm{b}}$ & $148.70^{\mathrm{a}}$ & $148.50^{\mathrm{c}}$ & 7.75 \\
\hline $\begin{array}{l}\text { Magnesium } \\
(\mathrm{mlg} / 100 / \mathrm{ml})\end{array}$ & $1.12^{\mathrm{a}}$ & $0.93^{\mathrm{c}}$ & $0.98^{b}$ & $0.98^{\mathrm{b}}$ & 0.63 \\
\hline Iron $(\mathrm{mg} / \mathrm{dl})$ & $42.10^{\mathrm{c}}$ & $42.20^{c}$ & $43.50^{\mathrm{b}}$ & $44.50^{\mathrm{a}}$ & 4.19 \\
\hline Phosphorus (mg/dl) & $5.00^{\mathrm{d}}$ & $4.80^{\mathrm{c}}$ & $5.61^{\mathrm{a}}$ & $5.55^{\mathrm{b}}$ & 1.14 \\
\hline Calcium (mg/dl) & $9.40^{\mathrm{d}}$ & $9.70^{\mathrm{a}}$ & $9.53^{b}$ & $6.71^{\mathrm{d}}$ & 1.97 \\
\hline
\end{tabular}




\section{Conclusion}

The result of this study showed evidence that cocoyam tuber meal could be included up to $30 \%$ in broiler starter production diet without any negative effect on the performance and mineral generation and therefore should be recommended for broiler production.

\section{References}

[1] AOAC (1999) Association of Official Analytical Chemists. Official Method of Analysis, $17^{\text {th }}$ ed. Washington D. C. USA.

[2] Agwunobi LN, Angwukam PO, Cora OO \& Idika MA (2002) Studies on the Use of Colocasia esculenta (Tora Cocoyam) in the Diets of Weaned Pigs. Tropical Animal Health and Production 34 (3), 24 27. http://dx.doi.org/10.1023/A:1015234709538.

[3] Allele SE \& Mays A (1999) The Merck's Veterinary manual $8^{\text {th }}$ ed. Merck and Co. Inc., White House Station, New Jersey

[4] Anon (2002) Poultry Rations and Feeding Methods. Manitoba Agriculture, Food and Rural Initiative.

[5] Duncan DB (1955) New Multiple Range and Multiple F-Tests. Biometrics 11, 1-42. http://dx.doi.org/10.2307/3001478.

[6] Edache JA, Musa U, Haruna ES, Esilome JO, Jibrin I, Okpale EJ \& Dogo IG (2005) Replacement Value of Guinea Corn for Maize in Practical Diet Fed Broiler Starter. Animal Research International 2 (2), 11-313.

[7] Henry RJ, Cannon DC \& Winkelnon JW (1972) Chemical Chemistry Principle and Techniques $2^{\text {nd }} E d$.

[8] Isidahomen CE, Omoikhoje, SO, Igene FU \& Osemota D (2009) Genetic Effects on the Comparative Biochemical Evaluation of Semen Mineral Status of First Chicken Strains. Ann. Conf. of Nigerian Society for Animal Prod. Calabar, March 18-21, P. 84-87.

[9] Merck Veterinary Manual (2011). Merck and Co. Inc. White House Station N.J.

[10] Merck Veterinary Manual, MVM, $\mathrm{http} / / \mathrm{www}$. marksveterinarymanual.com/MVM/htm/2/3200.

[11] Oko OOK \& Agiang EA (2009) Phyto-chemical Evaluation of 3 Extracants of Aspilia Africana Leaves Proc. Int. Conf. on Global Crisis, FUTO Owerrri, Nigeria. Pp. 89-92.

[12] Okon BI, Obi MB \& Ayuk AA (2007) Performance of Quails (Cournix japonica) fed Graded Levels of Boiled Sun-dried Taro Cocoyam (Colocasia esculenta) as a Replacement for maize $32^{\text {nd }}$ Annual Conf. of the Nigeria Society for Animal production.

[13] Olumu JM (2004) Nutrient Requirement of Broiler Chicken as Percentages; Miligrams or Unit per Kilogram Diet in Monogastric Animal Nutrition Principles and Practices. Pp. 70-72 Jachen Publication.

[14] Onyekwere MU, Olabode AD, Okechukwu SO \& Iheukwumere FC (2010) Effect of feeding boiled Bambara nut (Voandzeia subterranea) waste on Performance, Haematology and Serum Biochemistry of Weaned Rabbits. Proc. 35th Conf. Nig. Soc. for Anim. Prod. 14 - 17th March, 2010, University of Ibadan, Nigeria. 